\title{
Reflections on the Philosophy of Innovation and Entrepreneurship Education in Chinese Universities
}

\author{
Yao Yao \\ Ideological and Political Theory Teaching Department of Yunnan College of Business Management \\ Yoyo3213081@163.com
}

Keywords: Philosophy; Innovation and entrepreneurship; The unity of knowledge and Practice

\begin{abstract}
From the backtracking of the historical evolution of education and the concept of entrepreneurship education, this paper points out that the return of higher education from the edge of the social production to the social production center is the progress of the realization of the unity of knowledge and practice. It is the American entrepreneurial education concept built up with the philosophy of knowledge and practice, which has accelerated the process of knowledge production and continued to promote the United States. Innovation. This paper holds that the concept of Marx's philosophy of practice education should be the ideological basis of innovation and entrepreneurship education in Colleges and universities in China, and the establishment of a community of equal cooperation between teachers and students is a long effective mechanism to implement the practice education of innovation and entrepreneurship, overcome the shortcomings of the single subject theory and divide the knowledge and practice, and realize the sustainable regeneration and cultivation of innovative and entrepreneurial talents.
\end{abstract}

\section{Introduction}

For a long time, there have been three popular philosophical interpretation models in the academic circles at home and abroad: First, the interpretation model of "Resolving the Horse by the Soviet Union", mainly understanding the Marxist philosophy with the philosophy textbook system of the Soviet model in the 20 s and 50 s of the 20 th century. The second is the interpretation model of "Ken Jiema", which mainly understands Marx's philosophy through some popular and controversial works of Engels in the late 19th century, such as Feuerbach and Anti-Duhring. The third is the interpretation mode of "Western solution to the horse", that is, to understand Marx's philosophy mainly in accordance with Western philosophical models. It should be said that the above-mentioned interpretation mode has a certain historical background and has certain historical significance, but it has major limitations that cannot be ignored. It is far from enough to explore the deep foundation of Marxist philosophy and the spiritual essence of the philosophical revolution. In essence, they are only in the outer circle. To truly solve the essence of Marxist philosophy, we must adopt a new model of "resolving the horse with horses", that is, directly facing the main text of the "first fiddler" of Marxist philosophy, pointing directly to the deep foundation of Marxist philosophy and truly revealing the philosophy of Marxism. Originality and the spiritual essence of epoch-making change in the history of human philosophy.

\section{Etymological Explanation of the Concept of Innovation}

"Innovation" is a new word in Chinese. There is no such thing as "innovation" in the various Chinese dictionaries published before the 1980s. However, there is an explanation for the word "chuang" in "Ciyuan", which mainly includes the meanings of "scar, sore, beginning, creation, punishment". Its main meanings are "destruction", "beginning" and "creation". "Innovation" in Chinese is a foreign word that was translated from English in the 1970s and 1980s, while innovation in English is an ancient word derived from the "Innovate" in ancient Latin. That is, "renew, create new things or change old things", mainly refers to "creating new things." According to the Webster Dictionary, there are two meanings: introducing new things or new concepts (to 
introduce something new) and innovations (to make changes). Innovation is "introducing new things, new concepts and manufacturing changes". The "manufacturing change" here makes the meaning of innovation more broad. The 1996 edition of the Modern Chinese Dictionary defines innovation as "abandoning the old and creating new ones". In addition, "creative" or "new" is also an innovative nature. It can be seen that the common meaning of the word "innovation" is very broad, the key is "new", and the new is a relative concept. Therefore, innovation is also a relative concept.

Therefore, from the explanation of the etymology of innovation, it means "creating" or "creating new". People often use "innovation" and "creation", "innovation ability" and "creativity" (referring to people's ability and power to create new things), "innovative" and "creative" (referring to people's thinking and practical activities) Innovative features) Equal use. "Innovation" focuses on "new", "first", "unprecedented", "never", refers to the first or first time to establish new theories, generate new ideas, and come up with new methods. Making new artifacts, etc., is a negation and transcendence of all "old", not an old illustration and reproduction. Before the 20th century, the word "innovation" was just a common word. Changes have taken place since the 20th century, especially in the 1990s, innovation has become a hot topic in the world.

\section{The Scientific Philosophy of Innovation Concept}

\section{As the Possibility of a New Analysis of the Philosophy of Science Category}

The development of philosophy at any time inevitably requires new and more universal categories to enrich, enrich and develop the philosophical category system. The philosophical category is the most general, abstract, and universal category. In what sense can the specific scientific innovation categories be transformed into the category of philosophy of science? Here we need to address the necessity and possibility and the problems that exist after the transformation. From the perspective of necessity, first of all, the history of human scientific development is a history of innovation. The objective process of scientific innovation requires philosophical understanding and summarization of it, especially since modern times, the pace of scientific innovation has been greatly accelerated, and scientific innovation The social role of the society has become increasingly prominent. The wave of information and knowledge economy that emerged at the end of the last century has made innovation the strongest voice of the spirit of the times. It is necessary to enhance and summarize innovations in philosophy. Second, the formation of the category of scientific innovation is the need to enrich and develop Marxist philosophy. As the essence of the spirit of the times, Marxist philosophy must become the primary concentrated theoretical representation of the spirit of consciously reflecting the spirit of innovation. This determines that it must be constantly innovated at any time, advancing with the times, and absorbing in practice. fresh blood.

\section{The Reality of Innovation as a Category of Philosophy of Science}

Philosophy is the essence of the spirit of the times. Philosophy of science is a philosophical reflection on science. Engels said: "With every epoch-making discovery in the natural sciences, materialism must change its form." The arrival of the era of knowledge economy, the new characteristics and new trends of scientific development and the inherent requirements of the development of scientific philosophy theory, these three aspects constitute the realistic basis for the concept of innovation to enter the field of philosophy of science, thus making economics, management, etc. The promotion of innovative concepts in specific disciplines becomes possible as the basic category of philosophy of science, and its conceptual meaning has been further expanded. Below, we will demonstrate the historical inevitability of the concept of scientific innovation in the field of scientific philosophy from these three aspects.

First of all, from the perspective of economic changes in the new era, scientific innovation is a category in the era of knowledge economy. From the perspective of epistemology, science as a kind of knowledge system is the correct understanding of the objective world obtained by human beings through experience or rationality. The ancient Greek natural philosopher Aristotle strictly divided human knowledge into different types of high and low, the most advanced scientific knowledge, which can be used to explore the universal laws of the universe and to explain the reasons for the 
changes of things. It can be seen that the problem solved by scientific knowledge is precisely the core part of knowledge classification in the knowledge economy. In a certain sense, this knowledge-based economy is mainly based on the production, storage, use and consumption of scientific knowledge. Economy.

Secondly, from the analysis of the actual characteristics and trends of the development of science itself, innovation is the essential requirement of the development of science itself. The occurrence and development of scientific theory provides the most important support for technological innovation. The process of technological innovation is extending, and the status of science in innovation is increasingly prominent. This provides a realistic basis for the entry of innovative concepts into the field of scientific philosophy. The development of science to this day presents two of the most distinctive features. The close integration of science and technology, that is, science and technology and scientific technology, is the first distinctive feature of the development of modern science and technology. The combination and interaction of science and technology and mutual transformation are more rapid, and a unified science and technology system is gradually formed.

Finally, it is necessary for us to explore the different meanings of the concept of scientific discovery from the historical clues explored by the philosophy of science, to seek the implications of innovation contained in it, and then to clarify the possibility that innovative concepts enter the field of scientific philosophy.

\section{The Study of the Philosophy of Innovation and Entrepreneurship Education in Colleges and Universities}

We can not simply negate the tradition in a simple way, nor can we simply use the foreign educational concept to use it, take the essence, go to its dross, combine China's national conditions, and follow the law of education.

\section{It is Necessary to break through the Idea that Innovation and Entrepreneurship Education in Colleges and Universities Ignores Practical Education.}

The knowledge of entrepreneurship itself is a kind of experience. It is not rooted in the existence of a priori, and it is the knowledge obtained by the test of practice by the human reason rather than the action of the leadership. The entrepreneurial knowledge based on the classroom teaching is a theory about the summary of the experience of the predecessors. It is an indirect knowledge. Even if the teacher instills the true insight into the students, it is only a hard theory for the students. It will not automatically bring up the growth of the students' spirit of innovation and entrepreneurship, and emphasizes its authority with the standard of examination. It only shackles the students' creative thinking growth. The entrepreneurial knowledge that really makes the students' sense of social responsibility, innovation, entrepreneurial will and entrepreneurial ability is not the constant and invariable theory of certainty is not the knowledge that students can bring to them. The actual entrepreneurial knowledge can only be effective in the process of every entrepreneur's practice. When the entrepreneur is experiencing the entrepreneurial dilemma, the surrounding environment stimulates the entrepreneurs to observe deeply, reviews the experience of the predecessors, conscientiously introspection, further puts forward the solutions to solve the difficulties, and carries on the practice test, can the students learn from the class and in the books. The transfer of knowledge enables students to gain true entrepreneurial insight.

In the era of knowledge dependent economic development, enterprises should keep the advantage of increasing marginal income without innovation. Successful entrepreneurship must be established on the basis of objective innovation, and the activities of innovation in the practice of entrepreneurial practice are varied, which can be the fundamental discovery of the basic theory of original innovation and the new technology of integration innovation. It can also be a new demand for creating the market, or a new business model for customers. These innovative activities are only a potential productive force. Whether these potential productive forces can be turned into real productive forces must be realized through entrepreneurial activities. 


\section{It is Necessary to Establish the Concept of Equal Cooperation between Teachers and Students in Innovation and Entrepreneurship Education in Chinese Universities.}

In the 17-18 century, from Ren e Descartes, "I think so I am in" to "the intellectual nature legislation" of ImmanuelKant, nurtured a single subject philosophy dominated by all things (the object), which has a great influence on the educational thought, although it has cast the modern individual subject to conquer the natural guest. The ability of the body also highlights the technical rationality of the industrial civilization, but the subject philosophy has opposed the subject and object of the unidirectional degree. The relationship between the teachers and the students is tense, the crisis of trust between people and people, and even the imbalance of technical rationality and value rationality. After the twentieth Century, the modern intersubjectivity philosophy of thought tried to dispel the opposition of subject and object and the theory of subject centrism, and sought a new transcendence, so the thought of reform of our educational system became blurred. Now the concept of "teacher oriented and student as main body" in the mainstream education ideology of our country is in essence the product of harmony between conservative thought and radical thought, but it can easily cause confusion in people's thought. Some people say it is "double subject theory" and "double center theory", but it always loses its focus in practice.

In order to enhance China's innovation and entrepreneurship, in addition to deepening China's science and technology system reform and increasing the support of the "enterprise-driven employment" policy, we should also accelerate the process of education system reform. The success of American entrepreneurship education, its essence lies in all : the realization of mutual assistance and encouragement between teachers and students is the key to the inheritance of ethics and hard work. We must establish the concept of equal cooperation between teachers and students, not only to create a democratic and equal cooperative teaching classroom, but also to create a new organizational system between teachers and students after the class, to build a cross-professional, cross-level teacher and student A community of innovative entrepreneurship education that works equally between the two. This is a long-term mechanism to better implement the educational ideas of innovation and entrepreneurship, overcome the shortcomings of splitting knowledge and behavior of single subject theory, and realize the sustainable regeneration of innovative and entrepreneurial talents.

\section{Conclusion}

Under the background of the current era of China's economic society entering the new normal, the importance of college students' entrepreneurship education has become increasingly prominent. We should be in accordance with the national "public entrepreneurship and innovation," the general requirements, the deepening of the philosophical theory of entrepreneurship education students, and effectively improve the scientific, relevance and effectiveness of entrepreneurship education for college students, for the construction of socialism with Chinese characteristics modernization transport wealthy High-quality entrepreneurial talents with innovative spirit and entrepreneurial traits.

\section{References}

[1]Shi Q L. On Target Localization and Contents of Innovation and Entrepreneurship Education in Colleges and Universities[J]. Journal of Changzhou Vocational College of Information Technology, 2012.

[2]Guan X, Qi W. The cultural roots of American Entrepreneurship Education[J]. Proceedings of the International Academic Workshop on Socialence, 2013, 50(1):572-577.

[3]Qian Z, Science S O, University N. Innovation Mode of Entrepreneurship Education in Colleges and Universities From the Perspective of the Triple Helix[J]. Journal of Jiangxi Normal University, 2015.

[4]Mcclure K R. Exploring Curricular Transformation to Promote Innovation and Entrepreneurship: An Institutional Case Study[J]. Innovative Higher Education, 2015, 40(5):429-442. 
[5]Song A H. On Integration Path of Innovation and Entrepreneurship Education and Logistics Professional Education in Higher Vocational Colleges[J]. Journal of Changzhou Vocational College of Information Technology, 2015.

[6]Yan H A, Gao X J. Research on the Innovation of University Entrepreneurship Education[J]. Journal of Hebei University, 2014.

[7]Lin C, Xie Y, Li H, et al. The Generative Logic and Construction Strategy of "Precision" Entrepreneurship Education Curriculum in Universities under the Concept of Crowd-funding[J]. China Higher Education Research, 2017.

[8]Wang X. Research of Innovation and Entrepreneurship Education in Colleges and Universities in the Era of Knowledge Economy[C]// International Conference on Management, Computer and Education Informatization. 2015.

[9]Wang X. Research of Innovation and Entrepreneurship Education in Colleges and Universities in the Era of Knowledge Economy[J]. 2015.

[10]Wang F, Luo H, Wang F, et al. Analysis on the Factors Influencing the Performance of Innovation and Entrepreneurship Education in Colleges and Universities[C]// International Conference on Education, Management and Computer Science. 2016.

[11]Cheng X, Zhang F P. Research on Curriculum Construction of Innovation and Entrepreneurship Education in Colleges and Universities Based on Key Competencies[J]. University Education Science, 2017.

[12]Zhang W H, Sun W J. Research on the mechanism of innovation and entrepreneurship education and ideological and political education[J]. Journal of Jiamusi Vocational Institute, 2017.

[13]Zhao C, Chen R, Office P, et al. Reflection on deepening the entrepreneurship education in colleges and universities[J]. Journal of Shanxi Agricultural University, 2017.

[14]Hong-Li S U. Research on the Construction of Innovation and Entrepreneurship Education System of College Students under "Internet + "[J]. Value Engineering, 2017. 